Elsevier required licence: (c) $<2018>$. This manuscript version is made available under the CC-BY-NC-ND 4.0 license http://creativecommons.org/licenses/bync-nd/4.0/ 


\section{On mineral sovereignty: towards a political theory of geological power}

Preprint draft. Forthcoming in Energy Research and Social Science, special issue on "Problems of method in the social study of energy and climate change" (eds. Jon Marshall and James Goodman).

Jeremy Walker ${ }^{\mathrm{a}} \&$ Matthew Johnson ${ }^{\mathrm{b}}$

\section{Abstract}

The Anthropocene thesis invokes the 'enormous geological power' of industrialism: driven by hydrocarbon combustion, manifest in planetary heating. Yet political theory has proceeded as if the organisation of geological power were incidental to history. Geological agency, we submit, is precisely what mining industries are organised to achieve, materially and politically. We propose mineral sovereignty as a term of method to analyse 'geological power' in its legible, institutional and intentional forms. We deploy it to excavate an entwined genealogy of state and corporation: one evident in the constitutional (or extra-parliamentary) technologies of sovereignty and property that order the appropriation and distribution of mineral wealth. Through three provocations, we 'stratify' the concept of sovereignty: in the 'royal metals' of early modern states; in the rise of neoliberalism as a re-privatisation of mineral-energy infrastructures against the claims of social democracy; and in anticipatory extensions of mineral sovereignty to outer space. Mineral sovereignty discloses methodological problems for energy and climate policy. Pre-analytical distinctions between public law and the private power of fossil capital imply a hierarchy and separation that cannot be presumed, but must be achieved. We must 'leave it in the ground': this requires the re-assertion of democratic control over the mineral estate.

\footnotetext{
${ }^{a}$ Corresponding author.

Lecturer, Social and Political Sciences

Climate Justice Research Centre, University of Technology Sydney

Jeremy.Walker@uts.edu.au

${ }^{\mathrm{b}}$ Doctoral Candidate, Social and Political Sciences

University of Technology Sydney

Matthew.R.Johnson@student.uts.edu.au
} 


\section{Introduction: from geological power to geological agency}

The Russian mineralogist and biochemist Vladimir Vernadsky is widely considered the founder of Earth systems science. His concept of The Biosphere (1926) presented a revolutionary synthesis, a solar-energetic planetary cosmology demonstrating the extent to which living matter was deeply entwined with the circulation and combination of minerals throughout the surface layers of the nonliving geosphere, from the deepest cracks of the Earths' crust, to the composition of gases at the uppermost atmosphere. Combining the thermodynamics developed by combustion engineers with the biochemistry of physiologists, Vernadsky presented life as the supreme geological force, and Earth's deep history of planetary transformation as profoundly unique. Vernadsky illustrated how the dynamic evolution of incredibly diverse organisms had, through their collective biochemistries, transformed the composition of mineral strata. He also presaged by a lifetime Crutzen's (2002) proclamation of an Anthropocene epoch.

$\ldots$ in our geologic era $[\ldots]$ - the era of reason - a new geochemical factor of paramount importance appears. [...] Man has introduced into the planet's structure a new form of effect between the exchange of atoms between living matter and inert matter [...] With man, an enormous geological power has appeared on the surface of the planet." (Vernadsky [1924], in Guillame, 2014: 138)

Before most, Vernadsky recognised the 'enormous geological power' of industrial modernity. From a bioenergetic perspective, this is a power consisting predominantly in the expansive energy flows harnessed through the systematic extraction and burning of the mineralised remains of countless generations of photosynthetic organisms, and realised in the utilisation of the heat released by combustion to transform ever more of the Earth into artefacts, or into 'the economy'. Writing before the sensitivity of the Earth's heat balances to disruptions of the carbon cycle was well understood by atmospheric scientists, he wrote that:

These masses of organic matter provide powerful sources of potential energy - "fossilized sun-rays" [...] They have been enormously important in the history of man, and considerably more so in the economy of nature. An idea of their scale can be obtained from the size of the known reserves of coal. (Vernadsky [1926] 1998: 147, our emphasis)

We have now caught up with Vernadsky's recognition of human 'geological power', but not as an 'era of reason'. Rather, as a power recognised in international political and scientific institutions only by virtue of the largely unforeseen and unwanted side effects of its exercise, by the threat it poses to the planetary economy of nature. This is a belated realisation of an unevenly distributed geochemical agency, exercised unconsciously in the "invisible and often unthought-of process" of energy use in the infrastructures of everyday life (Hirsh \& Jones, 2014). Who witnesses the emissions generated in heating limestone to $1450{ }^{\circ} \mathrm{C}$ to make concrete, that ubiquitous anthropogenic geological formation?

Vernadsky was among the earliest to provide a scientific framework that could apprehend the 'enormous geological power' of techno-scientific, thermo-industrial civilisation to alter the biogeochemical structure of the Earth's enveloping spheres (atmosphere, biosphere, hydrosphere, cryosphere). In doing so, he completed Darwin's evolutionary account of human connection with all other life through the deep time of speciation and common descent, by demonstrating in space our completely dependent enfoldment within a multispecies biosphere that maintains habitable environmental conditions for life on the Earth's surface through photosynthesis. 
According to Grinevald (1998), the Vernadskyan revolution would be realised in the social sciences by the Romanian economist Nicholas Georgescu-Roegen. In his incisive, deftly-ignored critique of orthodox economic theory, Georgescu-Roegen (1971) excoriated economists for their faux-scientific pretentions, manifest in their unexamined commitment to ever increasing returns to scale, or in other words, to infinite industrial growth. With its methodological insistence that the 'foundations' of economic life lie in the subjectivity of 'individuals' in market exchange, economic theory embodies an ignorance of the history-making materiality of the economic process, and of the energetic and ecological implications of the laws of thermodynamics constraining it. The crux of GeorgescuRoegen's thesis is that "the issue of returns boils down to that of returns to mining and agriculture" (1971: 196). Agriculture is limited by the portion of the Earth's surface that can support photosynthetic organisms. Mining is limited by its inherent logic of depletion: in the inexorable dissipation of hydrocarbon energy stores via the irreversible process of combustion, and in the tendency of high grade, easily accessible minerals to be exhausted first, forcing mining operations into increasingly technically demanding, and economically marginal locations - or into direct competition with agriculture or protected areas for land rights. ${ }^{1}$ But if Georgecu-Roegen provided scientific foundations for ecological economics, he did not attempt to offer a political theory of the constitutive conditions - social, legal, institutional - by which the utopia of infinite industrialization powered by fossil energy (and to a lesser extent radioactive elements) became the task of all major nation-states. Nor did he point to any political remedy.

The concept of the Anthropocene is now familiar in the interdisciplinary settings where climate and energy policy are debated. It posits an epochal break in the chronology of the Geologic Time Scale, in which human action, amplified by fossil-fuelled machine technology and the wider set of pyrotechnical industries integral to modern economic organisation, emerges as the prime biogeochemical force of an unprecedented and irreversible transformation of the Earth. As many critical thinkers have remarked (Swyngedouw \& Ernston, 2018; Altvater et al. 2016; Malm \& Hornborg, 2014), the Anthropocene as a scientific concept does not translate well into the social sciences. It dissolves the uneven historical and social distribution of responsibility for the fiery terminus of the Holocene biosphere to a unitary Anthropos or 'human species', innocently exercising a destructive pyro-geological agency as if it were naturally the collective destiny of 'our speciesbeing' to do so. Diffusing responsibility into the vast abstraction of an 'epoch' depoliticises and offstages the deep challenge to political theory and practice presented by the problem of 'geological power'.

It is not our intention to directly engage the now voluminous debates on the Anthropocene concept. Rather, our interest is on the question of how geological power becomes geological agency, where agency refers to the political capacity of specific social subjects to act intentionally, perhaps against the will, interests or rights-claims of others. Given the divergent reality of access to the energy intensive lifestyles of the global consumer class, given the urgent need for a rapid de-carbonisation of energy infrastructures, how can we conceptualise 'geological agency' with sociological and material precision?

\section{Sovereign is she who decides the state of extraction}

In this article we propose the term mineral sovereignty to analyse 'geological power' in its historically organised, legible, and institutional forms. Geological agency, we submit, is precisely what the mining industries are organised to achieve, materially and politically. If this term is to date 
surprisingly absent in political and legal theory, it seems to us indispensable if we are to follow Clark's methodological challenge "to think the social and the political stratigraphically" (2017: 228). As Mumford once observed, "more closely than any other industry, mining was bound up with the development of modern capitalism" (1962: 74). ${ }^{2}$ Whilst inclusive of the phenomena of "carbon democracy' (Mitchell, 2009) and 'fossil capital' (Malm, 2016), mineral sovereignty denotes the more general politico-legal field of the extractive, pyrotechnical, and metallurgical industries, pointing to the taproot of military and economic power. Mineral sovereignty is evident in the formal state power to confer legality and legitimacy upon mining operations. Mineral sovereignty is also extraparliamentary, evident in the historical capacity of mining capitals to shape the political environment and legal architectures of the territories they operate in, to the extent of state capture, 'regime change', or transgression of international law. Open war may endow the strategic imperatives of extraction with 'the force of law'. Yet as history also shows, mineral sovereignty can be claimed by the constituent power of a people's movement, and domesticated by politico-legal innovations in the laws binding states.

Our methodological starting point reverses the surprisingly common presumptions of much of the climate, energy and environmental policy literature, in which scientifically-informed debate amongst political representatives ought to result in laws which corporations will duly conform to, in order to retain a social licence to operate over the period in which fossil fuel combustion is to be phased out. A very different story emerges from the long history of mining capital's influence over local forms of political life, especially in respect of control over fossil energy resources, and more recently, in the coordinated obstruction of international climate action. We would argue that common pre-analytical distinctions between state and market, between the public law of parliaments and the private law of transboundary corporations, presume separations that cannot be presumed. For projects such as energy democracy (Burke \& Stevens, 2018), climate justice (Goodman, 2009) and Earth democracy (Shiva, 2016) to succeed, the sovereignty of the people over the mineral estate is something that must be achieved.

\section{Mineral sovereignty as method}

We stake a claim to the term 'mineral sovereignty' on the basis that it has not yet been explicitly theorised as such. As far as we can determine, the term has been coined twice (Filer 1996:13; Emel, Huber \& Makene 2011:73), by writers spontaneously gesturing toward the geopolitical powers of mining corporations in ex-colonial territories (Papua New Guinea and Tanzania, respectively) under the conditions of neoliberal international economic order. Here, we propose to 'think with' mineral sovereignty, suggesting initial conceptual development of its implications.

We offer this hybrid term as a provocation for methodological diversity and interdisciplinary research in political theory and cognate fields of inquiry. This is in the spirit of terminological innovation arising from scholarly recognition that our planetary crisis is in some sense a question of culture: of the separation of fact and value, of subject and object formalised in the division of the natural and human sciences in the Western intellectual tradition. This can be seen in the proliferation of scholarly journals bearing titles which appear to be 'ontological hybrids' from the point of view of traditional divisions of academic labour, such as the Earth Law Journal (founded 1975), the Journal of Political Ecology (1994), Ecological Economics (1989) and Environmental Humanities (2012). The proliferation of hybrid terms to name emerging transdisciplinary research agendas, and the methodological innovations which accompany them - such as multispecies ethnography, composting feminisms, and energy humanities - are rather invitations to become reflexive about the limitations of 
classical methods and creative in working beyond them. What else but an ecology of methods can overcome the silo effects of the 'two cultures', to which Snow (1959) attributed the political incapacity of society to respond to Promethean technologies? We are mindful of Indigenous calls for decolonising methodologies (Smith, 2013), and Kopenawa's (2013) critique from Yanomami ontology of 'the white people': destructive 'earth eaters' deranged by 'metal smoke', 'cannibal gold' and 'merchandise love'.

The legal geographer Irus Braverman argues that "debates about method can be proxies for disagreements over theory [...] disagreements about whether research should be ideographic or nomothetic, debates between positivists and postpositivists, human and more-than-human geographers are often methodological differences which structure the underpinning of various geography projects" (2014: 123). Unlike concepts in the natural sciences which can be clarified empirically through experimental repetition and generalised beyond their incidental origins in particular states or societies, political concepts - justice, law, rights - are inherently contestable. As such, it is not our intention to review the repertoire of social science methods for their utility in specific projects of climate and energy research. Rather we argue that the first task of critical analysis is the clarification of concepts, as for Gadamer: " [a] consciousness of the history of concepts becomes a duty of critical thinking" (in Müller, 2014: 75). The hermeneutic or interpretive approach of a 'sociology of concepts' is the historical method we attempt to follow, in developing an approach to sovereign power that emphasizes the subterranean genealogies of political and economic institutions in the organisation of mineral/energy extraction.

In the remainder of this article, we attempt to develop mineral sovereignty as a cogent explanatory concept and a tool of historical method. Offering first to clarify the concept of sovereignty, we attempt to show how acknowledging the deep powers of the subterranean may update political theory, revising standard accounts of political power in geological terms. We do this through three necessarily brief sketches of past, present and future-oriented formations of mineral sovereignty: 1) the early modern capitalist state, 2 ) the organisation of neoliberalism as a political project now approaching an international constitution for globalisation, and 3) pre-emptive legal innovations that anticipate expansions of mining beyond the Earth to asteroids and other celestial bodies.

This historical narrative is intended to delineate the concept of mineral sovereignty. As we approach the present, we deploy it with a 'network analysis' method that seeks to trace specific forms of political organisation through which geological power has been consolidated into the era of global warming. We consider the ascent of the 'neoliberal thought collective', whom we identify with the membership of the Mont Pèlerin Society and think tanks affiliated with the Atlas Network. In this, we follow the method of Mirowski and Plehwe in the Road from Mont Pelerin (2009: 4), but dig further into a material dimension generally absent from genealogies of neoliberalism: namely, its links with the extractive and combustive industries that metalled the road and fuelled the car. We conclude by suggesting the value for climate and energy policy research of network-oriented methods that move us beyond depoliticised conceptions of geological agency through critical analysis of its organisation and exercise. Such methods offer but one possible approach for future projects exploring 'mineral sovereignty'.

\section{Rethinking sovereignty}

Sovereignty, the authority manifest in the powers of decision and coercion which order a given territory, is among the most basic and controversial of concepts in political theory and international 
law. The $16^{\text {th }}$ century French jurist Jean Bodin is credited with the earliest secular theory of the state, and was one of the first to have noted the ambiguity between sovereign power and law. On the one hand, sovereignty is that power that gives law its authority, force and legitimacy in a given nation and territory, binding and constituting the rulers and ruled as a political community. On the other, it is that power ordinarily constrained by constitutional limitations upon executive authority, a power revealed most nakedly when the declaration of an exceptional threat to security justifies the suspension of legal norms (Schmitt, [1922] 1985: 5-9). A conventional genealogy of sovereignty might trace its gradual devolution from the mystical union of the King's body with the Kingdom in medieval political theology (Kantorowicz, 1957) through to the popular sovereignty of republican democracy (Habermas, 1997). Thence, exceptional detours through the camps of totalitarian states notwithstanding (Agamben, 1998), to the vanishing sovereignty of neoliberal globalisation, which allegedly diffuses the sovereign decision into 'the market' - a spontaneous aggregator of the countless instances of free choice by which a denationalised body-politic of individuals exercise 'consumer sovereignty'. This sketch serves merely to illustrate the absence of materiality in standard theories of sovereignty.

Enlightenment theories of political life claimed to analyse and conduct political discourse in the cool, clear, illuminating light of reason, relegating the hot and dirty fires of the smelter, foundry, refinery, power plant and motor to the underground (Marder, 2015). Foucault, for many the post-

Enlightenment political philosopher par excellence, did not turn his analysis to the relation between biopolitical power (the sovereign power to make subjects live and die) and the geopolitical power of oil, coal, gas and uranium, to name only the most strategic of minerals to industrial civilisation's overwhelming capacity to accumulate wealth in some places and to devastate in others. Foucault's fascination with the Iranian Revolution made little of the problem of Iran's vast reservoirs of oil, that most combustible and coveted species of geological power. The question of ownership and control of the oilfields and distribution networks was and remains crucial for much of Iranian constitutional and revolutionary history. ${ }^{3}$

Clearly, there is a mineral aspect to the question of sovereignty. As Elden (2013) observes, customary understandings of territorial power are well-expressed in the military command to 'secure the area': a cartographic view of land as a flat space across which are plotted the borders and capitols of legal order. This underplays the imperative to secure strategic 3-dimensional spaces, or 'volumes'. It is surely vital to political accounting to estimate the volume of oil and gas in the mineral estate, and to wield 'vertical power' over geological surveys, and the bore holes and drill shafts which penetrate into geological strata. Whether state-owned or state-owning, it is often the most vertically consolidated of corporations running the business of mining.

Sovereign is he who decides the state of extraction: who decides the access rights, labour conditions, and revenue obligations of the mining concessions, and responsibility for the consequences of downstream pollution flows. From the police cell to the presidential palace, the operative conditions of energy exploitation frequently translate into the political conditions of the nation as a whole, and in turn its regional and international relations. Angola, Azerbaijan, Bahrain, Bolivia, Chechnya, Congo, East Timor.... Saudi Arabia, Venezuela, West Papua. We need not list more nations where mineral extraction and the distribution of resource rents are key factors in exceptional histories of revolution or counter-revolution of constitutional order. In this sense, the control of mineral wealth can be said to be constitutive of the political. This is also true of 'normal' jurisdictions like Australia, Canada and the United States, where governments have proved unable to reign in the ambitions of fossil capital or have acted as its executive arm, legislating for 'energy security' and against movements for carbon 
taxation, renewable energy, climate response, Indigenous land rights, or environmental protection. This leads us to consider the question of how law relates to the base materiality of planet Earth.

Liberal philosophies of law and economics have long been criticised, from the traditionalists and nationalists of the right to the eco-Maoists and anti-imperialists of the left, for evading the 'foundational' political questions of land that arise with the de-territorialisation of global capital flows. The erudite account of terrestrial order provided by the conservative constitutional theorist Carl Schmitt has thus been widely influential in recent legal and political geographies (eg. Wainright \& Mann, 2013; Minca \& Rowan, 2016), despite his entanglement in the jurisprudence of the Third Reich. Schmitt's Nomos of the Earth (2006 [1950]) begins with the following statement on the primacy of land in all law and order, not just that explicitly concerning title in land and natural resources. For Schmitt (2006: 42), the earth, "the soil' is "the mother of law":

...the earth is bound to law in three ways. She contains law within herself, as a reward of labor; she manifests law upon herself, as fixed boundaries; and she sustains law above herself, as a public sign of order. Law is bound to the earth and related to the earth.

Deployed as a critique of the ungrounded normativity of liberal constitutional law, Schmitt's genealogy of law as nomos is mobilised against what he saw as inadequate interpretations of ancient Greek terms. Plato's nomos represented "a mere rule" over land (p. 67), while Aristotle did better in interpreting nomos as an "original distribution of land" (p. 68). From here, Schmitt derives the law of the land from ancient customary rights to grazing grounds. This is implicit in the Greek word for the herdsman (nomeus), who was originally a nomad, later becoming the guardian-manager of an estate, or 'economist' (oikos + nomos) (p.339-340). For Schmitt, "The Greek word for the first measure of all subsequent measures, for the first land-appropriation understood as the first partition and classification of space, for the primeval division and distribution, is nomos" (p.67). In pre-industrial legal traditions, rights to land, soil, water and other life-sustaining resources are nominally framed as obligations to the common interest in sustaining food production - and in securing the life of the nation from external attempts at land appropriation. Yet the administration of the modern industrial order cannot be understood in terms of the attachments to soil of agrarian conservatives. German politics in Schmitt's lifetime was surely less determined by 'blood and soil' than by coal and iron: by the grave geopolitical contests involving the giant cartels of heavy industry built upon the collieries of the Ruhr valley (Gillingham, 2014).

Let us suggest that Schmitt's claim that "land appropriation [is] the primeval act of founding law, [the] terrestrial fundament" from which both the dominium of private law and the imperium of political authority are derived $(2006$; 45-47) be revisited in light of sovereign claims to the $s u b$-soil, and of the geopolitical powers of extractive capital to exceed and overwrite legal processes nominally grounded in the lifeways of the common land. If "the constitutive process of a land-appropriation is found at the beginning of the history of every settled people, every commonwealth, every empire" (p.48), then perhaps no more exemplary expression of mineral sovereignty can be found than the 1916 Mineral Ordinance decreed by the colonial government of Nigeria, which asserted the sole ownership by the British monarch of the subterranean geology of Nigeria. Section 3(1) of the Ordinance declares that :

The entire property in and control of the minerals, and mineral oils, in under or upon any land in Nigeria, and of all Rivers, streams and water courses, throughout Nigeria, is and shall be vested in the Crown (in Raji \& Abedjie, 2014: 66). ${ }^{4}$ 


\section{Royal metals}

The English gold sovereign coin illustrates in compressed form the combined powers of mineral and state sovereignty: stamped with the face of the sovereign monarch, it embodies the undivided claim of the sovereign state to be the sole issuer of currency, to tax, make law, declare war, and extend Crown control over territories in which mineral wealth lies buried. Mineral rights - formally vested in the state but frequently delegated to privateers, joint-stock companies and corporations - are a politicaleconomic institution that has traversed and irreversibly changed the Earth.

Writing in the grand style of technology studies prior to the 1970s dawn of the 'age of ecology', for the economic historian John Nef the European history of mining and metallurgy represented nothing less than The Conquest of the Material World (1964). Nef recalls the mineral histories that preceded the 'coming of the industrial state' to all nations. This is the history of the development of modern science and mechanical engineering, from the applied geology of mineral exploration through the applied chemistry accompanying the development of smelting techniques for novel alloys, the basis for the multiplicity of pyro-technologies developed by industry. Analysis of heat and combustion in the blast furnaces for iron making were key to modern chemical theories which followed the isolation of carbon and atmospheric gases (Wertime, 1954). Problems of work and power in steam engine design drove modern physicists to synthesise theories of heat and material transformation in the laws of energy and entropy. For Nef, the history of mining and metallurgy is equally the history of modern social, economic and political organisation. The momentous techno-economic shift toward ubiquitous use of coal, iron and heat engines was preceded by a longer developmental expansion of mining activity in other minerals, and of the political technologies of sovereignty and property associated with this.

Cuius est solum, eius est usque ad coelum et ad inferos. According to this Latin maxim dating to the $13^{\text {th }}$ century, "the owner of the soil has a prima facie ownership of everything reaching up to the very heavens and down to the depths of the earth" (Gray, 1991: 253). The ad coelum doctrine would be enshrined in English legal commentary by Sir William Blackstone,

"Land hath also, in its legal signification, an indefinite extent, upwards as well as downwards... whatever is in a direct line, between the surface of any land and the centre of the earth, belongs to the owner of the surface; as is every day's experience in the mining countries. So that the word 'land' includes not only the face of the earth, but every thing under it, or over it.” ([1753] 1893, Book II, ch.2, para.18)

In the twentieth century, access to airspace and outer space would place upper limits on atmospheric property over land. But long before the legal revolutions that would abolish feudal titles and establish markets in land as capital asset and exclusive private property, there were sovereign exceptions to landholders' rights in the subterranean. $\operatorname{Nef}(1962: 16)$ describes the Regale, the claim of the sovereign to authority over land bearing precious metals. Frederic Barbarossa (1155-1189) claimed the regale as an attribute of his imperial sovereignty, and pressed claims for a share of all gold and silver mines in the Holy Roman Empire. In many jurisdictions the right of the overlord to claim ownership over metals, especially the 'royal metals' of gold and silver, was to become supreme over the rights of the manorial 'lords of the soil' with their agricultural rents and forest privileges. But in practice this required the delegation of authority and negotiation: rents, or 'royalties' could not be set so high as to discourage industrial activity that royals themselves were not interested in doing. 
"...few holders of the regale had successfully put forward a claim to the base metals in the lands of private owners... within their territorial dominions. Someone, however, had to assume responsibility for orderly mining and for settling disputes between groups of miners, at a time when mining was still carried on largely by small bands of workpeople who claimed a share in the ownership of the ores by virtue of the technical ingenuity they exercised and the manual labour they performed." (Nef 1962, p.17)

In ancient Rome most mining was performed by slaves. By contrast, medieval mining involved relatively autonomous companies of highly skilled, free workers, with their own charters and rights, and with privileges often greater than those of towns emerging around textiles and other non-metal manufactures. In Germany, where the techniques of mining and metallurgy were most advanced, the word for 'mountaineer' and 'miner' was the same. Envied by serfs bound to labour for the 'lord of the soil', the miners travelled to wild places, seeking exposed surface ores of silver, copper, gold, iron, and abundant forests to cut for fuelwood and charcoal for small-scale open-air smelting. Patterns of 'settlement' in Europe owed much to the migrations of German miners: "The movement to colonize and to mine went hand in hand" (Nef, 1962: 12).

As the scale of production increased, mining works became less ad hoc, more capital intensive and less mobile, sited by fast running rivers to drive more powerful machines that blew air on the smelting fires and drove batteries for the crushing of ores. The financing of larger and more permanent smelting and battery works, and of deeper mines deploying grander drainage and ventilation systems, demanded ever larger sums and combinations of investors. To this Nef attributes the emergence of specifically capitalist forms of industry, predicated on the division between capital and labour. Shares in mining companies - once, to a considerable extent, held by and exchanged between miners themselves - were transferred to more powerful players. Thus arose a class of professional mine managers, acting on behalf of wealthy absentee owners and royal revenue collectors, with the miners themselves increasingly cheapened to wage labourers with no rights in their product or share in the profits.

Regalian rights to mines were closely related to regal privilege to mint, to be the sole coiner of currency, and thus to administration of the treasury (and by extension, of national economy). The inspection and administration of mining works to protect royal property and revenues was closely related to the rise of the centralised nation-state. English monarchs would reassert their regalian rights in the 1556 'Case of Mines' ( $R v$ Earl of Northumberland), in which the Court decided in favour of the Crown, Elizabeth I, stating that:

"by the law all mines of gold and silver within the realm, whether they be in the lands of the Queen, or of subjects, belong to the Queen by prerogative, with liberty to dig and carry away the ores thereof, and with other such incidents thereto as are necessary to be used for the getting of the ore" (cited in Colman 2010).

In the wake of the Case of Mines decision, the Crown extended its dominion over metals, establishing royal monopoly through two charter companies: the Society of Mines Royal and the Company of Mineral and Battery Works. Much like the Germanic miner-colonisers described by Nef, the granting of letters-patent to skilled merchants capable of exploiting resources aimed to benefit the imperial economy, developing productive industry while raising revenue through the collection of rents (Hyde Price, 1906; 14-16). The 1568 Charter of the Society of Mines Royal included rights "to search dig 
open roast melt stamp wash drain or convey waters or otherwise work for all manner of mines or ores of gold silver copper and quicksilver" (in Carr 1913; 4). The charters of the Company of Mineral and Battery Works extended royal monopoly over copper, zinc, alum and iron, along with gold and silver and the mercury used in refining them from mixed ores.

The organisation of corporate forms of private property, risk bearing, joint-stock capital and mercantile enterprise in the royal charter companies would become, with the colonial conquest of the New World and Asia, privately owned, for-profit extensions of the sovereignty of the Crown, the vanguard of world Empire. Whereas the above charters above would codify forms of mineral sovereignty in England, charters with privateers and companies would extend royal claims to precious metals into the New World. For example, Elizabeth's charter for the exploration of Virginia, granted to Walter Raleigh, would grant the right to "holde, occupie, and enioye to him, his heires and assignes, and euery of them for euer, all the soile of all such lands, territories, and Countreis, so to bee discouered and possessed [sic]." But as for royal minerals, the Crown would:

"[reserve] always to us our heires, and successors, for all seruices, duties, and demaundes, the fift part of all the oare of golde and siluer, that from time to time, and at all times after such discouerie, subduing and possessing, shal be there gotten and obtained" (in Thorpe 1909; 54).

Sovereignty over gold and silver was not limited to the British Empire, of course. Focusing on the Potosí silver mine of Peru, Moore (2010) describes how the violent exploitation of New World silver by the Spanish Empire in the 16th century would radically transform the social-ecological systems of the Americas, accelerating the development of the broader capitalist world-system. Silver inflows from the Americas become a vital stream of income for the Spanish Crown, ultimately leading to imperial decline through a protracted period of agricultural crisis, inflation and rising national debt. American silver was also vital in maintaining monetary-stocks and money-capital formation across Europe (Moore 2010: 64-65, 59). Potosí silver would become the cash-basis for the Dutch Republic and its East India Company, providing the momentum for multiple European sovereigns' dominion over ever larger expanses of territory.

Beside the 'money fetishism' of metal currencies in the mercantile era, the growth of mineral output and general proliferation of metal wares lead to seismic shifts in industrial organisation. Rather than finessing the aesthetic qualities of silver wares for elite customers, which was the dominant priority in France (Nef 1962), by the seventeenth century foundries in England were increasingly organised according to the over-riding principle of increasing output, especially of ironwares. This drive to achieve efficiencies in the maximisation of production, recognised in Adam Smiths's famous analysis of the pin factory, was one of the key reasons why Britain would become in the following century home to the momentous shift from wood, wind, and water based energy flows to the great burning of the vast Carboniferous 'subterranean forest'. The technological development of machinery for mining operations would culminate in the 1698 Savery steam engine. Burning coal to power a water-pump, it made viable ever deeper coal mine shafts, thus inaugurating the amplification of mineral fuel combustion at the heart of the Anthropocene predicament.

\section{King coal, black gold: neoliberalism as resistance to carbon democracy}

Conflicts over the exploitation of mineral resources and distribution of mineral wealth are central to geopolitical history. The authority to grant rights to mine and assert property in extracted minerals, to regulate mining profits and labour, to claim royalties and revenues, and to oblige companies to be 
responsible for environmental damage goes to the heart of questions of state, national and popular sovereignty. In particular, the development of global commodity chains of carbon-based mineral energy brought with it sites of struggle, contestation, class-compromise and violence, both within the territorial space of established industrial powers and in the colonial frontiers of imperial expansion.

Remarking on the hazardous and debilitating conditions of the English mining proletariat, Engels exclaimed: "this is not the steerage of an American slave ship, it is the dwelling of freeborn Britons!" ([1887] 1998: 201). Counter-movements against wages below the level of subsistence were vital to the mass politics of the $19^{\text {th }}$ and early $20^{\text {th }}$ century, triggering in Britain the revolts that resulted in the Chartist movement for universal suffrage. Such mobilisations against the dominion of mineral sovereignty over life and labour were made possible by the new forms of economic, social and labour organisation that emerged alongside coal-fired industry. Mitchell (2009) describes how mass urbanisation and the proliferation of manufacturing lead to a concentration of labour previously impossible through the solar energy chains of firewood, agriculture, water and wind. With carbon fuels,

"Great quantities of energy now flowed along very narrow channels. Large numbers of workers had to be concentrated at the main junctions of these channels. Their position and concentration gave them, at certain moments, a new kind of political power. The power derived not just from the organizations they formed, the ideas they began to share or the political alliances they built, but from the extraordinary concentrations of carbon energy whose flow they could now slow, disrupt or cut off." (Mitchell, 2009: 403)

Following industrial actions of coal-miners in the late $19^{\text {th }}$ and early $20^{\text {th }}$ century, labour reforms were introduced in Germany, Britain, Canada, Australia and (some of) the United States. ${ }^{5}$ From the bowels of coal mines emerged nascent forms of electoral democracy and the welfare state, suggesting a domestication of mineral sovereignty by broadly social democratic doctrines of popular sovereignty exemplified in the 1945 election victory of the British Labour party over the Conservative wartime leader Winston Churchill. In order to achieve the goals of post-war reconstruction and the rollout of the welfare state, Clement Attlee would nationalise the coal and steel industry, as well as gas, electricity, and rail networks, a strategy which would be taken up by Keynesian governments in the West and anti-colonial nationalists in the developing world. Friedrich Hayek, who would become the most eloquent opponent of social democracy, warned that the problem with the nationalisation of utilities was that "[t]he machinery of monopoly becomes identical with the machinery of the state" (Hayek, [1944] 2007: 207). There is a certain evasiveness in Hayek's implication that private monopolies had never sought precisely such a situation - to the disadvantage of the demos. ${ }^{6}$

Diplomats seeking a peaceful settlement between the nations of Western Europe were similarly preoccupied with the domestication and subjection of heavy industry to the goals of shared prosperity and collective security. When the governments of France, Belgium, West Germany, Luxembourg, Italy and the Netherlands signed the Treaty Constituting the European Coal and Steel Community (1951), they accomplished a legal and political innovation which, beginning with the European Court of Justice established in 1952 to adjudicate the treaty, laid the groundwork for the civilizational project of the European Union. The agreement to surrender mineral sovereignty to a supra-national federation was intended to make another world war initiated by European nations 'not only unthinkable but materially impossible' (Bebr, 1953). 
The spectre of the de-privatisation of mineral sovereignty had already alarmed US industrial interests into active sponsorship of conservative social science and the organisation of networks of corporate influence to oppose these developments. The positions of Friedrich Hayek and Lionel Robbins at the London School of Economics, and of many among the European network of liberal intellectuals attending the 1938 Colloque Walter Lippman - which reconvened at the inaugural 1947 meeting of Hayek's Mont Pèlerin Society (MPS) - were funded ultimately by oil wealth in the form of Rockefeller Foundation grants (Fisher, 1980). ${ }^{7}$ The private University of Chicago, established by John D. Rockefeller with foundation grants from his Standard Oil fortune, would become the US base of the neoliberal movement established by Hayek, Aaron Director, Milton Friedman and fellow MPS members in the Economics and Law faculties (Van Horn \& Mirowski, 2009). Harold Luhnow of the Volker Fund, among the wealthy businessmen courted by Hayek to finance his project at Chicago, proved unwilling to sign off on funding to a cadre of scholars including Hayek's initial nominee, the 'old' Chicago economist Henry Simons. ${ }^{8}$ Simons propounded the classical liberal view that:

The great enemy of democracy is monopoly, in all its forms: gigantic corporations, trade associations and other agencies for price control, trade-unions - or, in general, organization and concentration of power within functional classes (Simons 1948, in Van Horn, 2010: 1530)

For Simons, gigantic corporations in association undermined the decentralisation of economic and political power afforded by market competition and the liberal democratic constitution. Their powers to impoverish the majority and undermine democratic oversight of the economy were such that the government should act to "destroy them" or risk a "usurpation of sovereignty", even a "domination of the state by them" (Simons 1948, in Van Horn, 2010; 1530). Following Simons' death by suicide in 1946, Volker funding was arranged for the Chicago Free Market Study (1946-1952), followed by the "postively pro-trust" Antitrust Project (1952-1958) (Dean, 2012: 74). These studies produced the founding papers of the neoliberal law and economics movement, which has since transformed US jurisprudence through the 'economic analysis' of law. Among the most influential papers were those critiquing the anti-corporate animus of the anti-monopoly Sherman Antitrust Act (1890), under which the Standard Oil empire was broken up in 1911 by the Supreme Court (Director \& Levi, 1956; McGee, 1958). With the critique of concentrated business power now pointedly absent from the "new liberalism' at Chicago, the stage was set for the prodigious influx of corporate 'philanthropy' into the Atlas network and affiliated academic departments from the early 1970s, as thermo-industrial capital mobilised to counter the nascent environmental movement's revolutionary legislative gains.

It is perhaps less than coincidental then, that the dawn of the neoliberal era in Western democracies would be heralded by Margaret Thatcher's union-busting, de-nationalisation and re-privatisation of UK coal, steel, gas, electricity, and railway networks - all mineral/energy based infrastructures. The ascent of neoliberalism might thus be interpreted as a reclamation by private capital of the powers of mineral sovereignty, for a time subordinate to egalitarian ideals of popular sovereignty and social democracy.

Liquid carbon fuels have often been linked to despotism and violent, interventionist foreign policy - a neo-colonialism in which the principle of permanent sovereignty over natural resources long asserted by developing countries in the United Nations is challenged and thrust aside by more powerful statecorporate partnerships. The Trans-Arabian Pipeline exemplifies the collusion between Western oil corporations, despotic client government and the protection of private property appropriated through imperial violence. ${ }^{9}$ The use of post-war Marshall Plan funds for construction of oil transportation facilities in the Middle East was a direct response to the militancy of European coal miners (Mitchell, 
2009: 406), part of a geopolitical strategy to shift Europe's energy consumption toward oil-based sources, favouring US oil corporations and reducing the strategic influence of industrial unions in European political economy.

Multinational mining firms have of course been active in the suppression of local dissent outside of carbon-based mineral extraction. Legitimising and facilitating free markets frequently involves distinctly illiberal, coercive means, beyond mere ideological persuasion to submit to 'the invisible hand'. This can be seen in the first implementation of neoliberal economic policy under Pinochet's military dictatorship in Chile. Socialist President Salvador Allende continued the previous Montalva government's acquisition of the largest US-operated copper mines, which were fully nationalised in 1971 following a unanimous vote on a constitutional amendment in Chile's Congress. At the time, the US war machine in Indochina absorbed 10 percent of all copper used in US industry, up from 1.5 percent in peacetime (US Congress, 1988: 13). Supporting the interests of mine owners Anaconda and Kennecott, the CIA (with explicit approval from Nixon and Kissinger) actively destabilised the Allende government, culminating in the 1973 Pinochet coup.

The Chicago School neoliberalism first experimented with under military dictatorship in Chile would inform a wholesale transformation of international financial, economic and legal order, to the extent that legal scholars now speak of a 'neoliberal constitutionalism' in both domestic and international law (Purdy, 2014). From the 1980s, neoliberal forms of rule were globalised in the form of the Washington Consensus imposed upon developing nations by the IMF and the World Bank in the form of 'structural adjustment policies', leveraging a shift from national welfarism and import substitution to export-led development and foreign direct investment, of which mining capitals' push for the denationalisation of resource development played no small part. The collaboration of MPS economists such as Milton Friedman and Arnold Harberger with the Pinochet regime was immediately public and contentious (e.g. Frank, 1976), but the influence of MPS political-legal theorists such as James Buchanan upon the Junta's 1980 rewrite of the Constitution of Chile deserves more attention (Fischer, 2009; Farrant \& Tarko, 2018). Buchanan's long-term project, the Virginia School of constitutional political economy, was discretely bankrolled by the petrochemical billionaire Charles Koch, a fellow MPS member (Maclean, 2017).

For the legal theorist David Schneiderman (2017), 'neoliberal constitutionalism' denotes an enforceable supra-national legal order of trade and investment treaties requiring states to harmonise their internal legal environments to allow frictionless capital mobility across borders. Crucial here are Investor-State Dispute Settlement (ISDS) clauses. These allow transnational corporations to seek substantial damages from parliaments enacting legislation that affects property rights in 'anticipated future profits', as has happened with Quebec's moratorium on fracking in the midst of an enormous expansion of Canada's tar sand oil and gas industries. Negotiated with little public scrutiny, such agreements instantiate a system of private law in which corporations can impose liabilities on elected governments, in extra-national venues in which citizens and their representatives have no standing to bring cases against corporations nor to have decisions reviewed (Colton, 2015). Numerous suits brought against governments involve challenges by transnational energy companies to the enforcement of environmental law; with amounts sought against some developing countries involving significant fractions of their GDP (Tienhaara, 2006). Translated into marketing and legislative strategies by an expanding roster of think-tanks, unfolded through a welter of agreements on trade and investment liberalisation, neoliberalism has morphed into a global form of legality, both basic and general, which intends to secure for business interests the free flow of trade and capital enabled and unimpeded by state policy. 
Nowhere perhaps has the fit between neoliberal organisation and mineral sovereignty been closer than in the theatre of climate and energy policy. The mobilisation of energy, mining, petrochemical and other resource intensive corporations against environmental science and legislation is well known, less so is the extent to which neoliberal political infrastructure has been directly associated with fossil capital. For example, the US-based organisations amongst the list provided by the Atlas Network of the 475 neoliberal think-tanks it coordinates, is almost identical to the list produced by Greenpeace of organisations funded by ExxonMobil to amplify science denial and hostility to climate and renewable energy policy in the public sphere. ${ }^{10}$ President Trumps' unilateral withdrawal of the US from the Paris Climate Accord (2018), his appointment of Rex Tillerson, CEO of ExxonMobil to Secretary of State, and his assaults on the Environmental Protection Agency exemplify a triumph in the long march of the neoliberal project to capture state power and re-privatise mineral sovereignty against international norms and institutions. ${ }^{11}$

At stake in rise of neoliberal constitutionalism are the nation-state's regulatory powers over the economy and the environment, and the subordination of the political-juridical sphere defined in democratic constitutional theory to the 'supreme law' of 'global market forces'. With little exaggeration, we might adopt Schmitt's term to describe neoliberalism as a 'nomos of the earth': a nomos with deep roots in the geopolitical agency of extractive capital, a constitutive ordering of geological power lending the force of law to the appropriation, distribution and dissipation of the resources of earth and sea. And soon, perhaps, of outer space.

\section{7. 'I would annex the planets if I could': mineral sovereignty beyond the Earth ${ }^{12}$}

Silicon Valley, aerospace manufacturing and extractive industry become curious bedfellows in the nascent space mining industry. The lightweight construction of spacecraft seems far removed from mining technology. Rapid deforestation, mountaintop removal, massive excavators, 200-wagon coal trains, tailings dams - the sheer scale and destructiveness of the resources industry is a contrast to the intricate fragility of communication satellites. Yet much of the venture capital funding space mining ventures like Planetary Resources and Deep Space Industries comes from fortunes made in 'information' industries, sometimes described as virtual, or post-industrial.

From this quarter comes an entrepreneurial culture now focussed on mining the planets, moons, asteroids and comets of the Solar System. Asteroids, for instance, may contain in abundance metals like cobalt, iron, niobium and platinum, unaffected by the biogeochemical history of the Earth. In Earth's early geological history, heavy siderophilic elements such as these were pulled into the planet's core and are comparatively rare in Earth's crust, while deposits nearer the surface are thought to have arrived as meteorites. Many relatively rare metals have become vital for hi-tech industry, from catalytic converters to renewable energy technologies.

The anticipation of future space mining industry is predicated on projections that the mineral basis for such industries could soon be depleted on Earth, but exists in abundance off-world. Moreover, space mining advocates believe such industry could reduce the costs of space colonisation by eliminating the need to transport heavy materials from Earth's surface. Start-ups are developing proposals for robotic in situ refining and manufacturing technologies with which to initiate the industrialisation of the Solar System. Whilst the space mining industry exists only in 'start-up' phase, mainstream mining corporations are interested. In the words of Sam Walsh, ex-CEO of Rio Tinto: 
"The logistical challenge is a major challenge. I'm physically sure that there will be minerals there, because we see that from meteorites. [...] when those places are developed, we'll be there" (Chatham House, 2015).

Whilst of course there are no fossil fuels beyond Earth, space miners are particularly interested in extra-terrestrial energy resources. Water ice can be split into hydrogen and oxygen, providing fuel for spacecraft and oxygen for crew. Helium-3, extremely rare on Earth and abundant on the Moon, is held to be a crucial component in the design of a viable fusion reactor - an unrealised technology often claimed as a potentially 'unlimited' energy source.

As manifest in recent US space legislation, this speculative project is predicated upon an interplanetary extension of the legal and economic institutions through which the geological agency of mining capital has historically operated. In 2015, Congress voted into law the US Commercial Space Launch Competitiveness Act - grounding the speculative space mining project in the legal authority of the United States. The Act is intended to accelerate "the development in the United States of economically viable, safe, and stable industries for commercial exploration and for commercial recovery of space resources" (CLSLCA $\S 51302$ ). The Act guarantees private property rights to any:

United States citizen engaged in commercial recovery of an asteroid resource or a space resource ... [who] shall be entitled to any asteroid resource or space resource obtained, including to possess, own, transport, use, and sell the asteroid resource or space resource obtained in accordance with applicable law, including the international obligations of the United States (CSLCA, 2015, §402).

A unilateral expression of mineral sovereignty, the CSLCA was passed in response to the lobbying of the predominantly US-based commercial space sector. Often described as 'NewSpace', this network of start-ups and lobbying organisations encompasses emerging space miners and established space launch companies like Elon Musk's SpaceX. Private property rights have been a core focus of NewSpace advocacy; advocates believe the right to use, own and sell space resources will trigger offworld industrialisation by the private space sector. The pre-emptive guarantee of ownership will enable financial calculation of profits, costs and risks, incentivising investment (Planetary Resources 2015). In the view of one author, writing for the Atlas-affiliated Competitive Enterprise Institute,

"... under the view of the universe as a frontier full of potential, the resources that could be developed from [outer space] offer great opportunity for human flourishing. Centuries of history demonstrate that the best means of doing that is via the free exchange of goods and services, undergirded by legally enforceable private property rights" (Simberg, 2012: 4).

In spite of frequent invocations of cosmopolitan and abundant futures 'for all humanity', NewSpace's strain of the Silicon Valley ideology is espoused predominantly by wealthy libertarians, often with links to the legal-ideological juggernaut of neoliberal thinktanks. Especially the Cato Institute (eg. Hudgins, 2002), founded by Charles Koch of the petroleum-based Koch Industries to exclude commoners from the common-wealth through further fortifications of property rights.

For NewSpace progenitor Gerard O'Neill, industrial exploitation of the mineral reserves of the Solar System was vital to overcoming ecological and regulatory limits to growth. Space mining advocacy often recognises the Earth's finite capacity to support life while simultaneously calling for infinite 
economic growth beyond it. In testimony before Congress, O'Neill (1975) asserted the recurring NewSpace refrain that when space resources are taken into account,

"[...] the 'limits of growth' are absurdly high: the total quantity of materials within only a few known large asteroids is quite enough to permit building space-colonies with a total land area more than ten thousand times that of the earth."

O’Neill would later confess that he had:

"[...] always felt strongly a personal desire to be free of boundaries and regimentation. The steady state society, ridden with rules and laws, proposed by early workers on the limits to growth was, to me, abhorrent" (in Kilgore 2003, 159).

These attributes of NewSpace discourse - disavowal of limits to growth, hostility to collective obligations manifest in law, faith in distant technological 'solutions' - clearly resonate with neoliberal policy rhetoric.

Reminiscent of maritime empires past, the 2015 Commercial Space Launch Competitiveness Act asserts jurisdiction over minerals in space at a time when appropriating them is far from technically feasible. It would appear that the US is pre-emptively extending a sovereign claim to the resources of the Solar System through the arms-length entity of the merchant corporation (Johnson 2018). ${ }^{13}$ The elite fantasy of refuge in space from social obligations and an increasingly inhospitable Earth may yet be just that - a fantasy - but it serves to illustrate the point that mineral sovereignty is inherent in the deep genealogy and cosmic imaginary of political power. Familiar terrestrial concerns of climate and energy policy are at stake here. State-corporate prerogatives of energy security and economic growth are to be secured through assertions of mineral sovereignty - in direct collision with the claims of popular sovereignty to manage the common wealth with laws of the people, by the people and for the people.

The US public law affirming the legality of private appropriation in the extra-territorial domain of outer space has triggered contentious debates over its conformity with existing international law. The UN Outer Space Treaty (1967), ratified during the height of Cold War hostilities, contains a clear 'non-appropriation principle':

Outer space, including the Moon and other celestial bodies, is not subject to national appropriation by claim of sovereignty, by means of use or occupation, or by any other means (Article II).

An international public law of the commons, it came early in a sequence of treaties and agreements governing global common spaces and common-pool resources such as the Antarctic Treaty (1959), predating the third UN Convention on the Law of the Sea (UNCLOS III, 1982) and the UN Framework Convention on Climate Change (1992). As the United States and Soviet Union threatened to bring Cold War hostilities to the space frontier, the United Nations claimed common sovereignty over outer space 'for all mankind'. The Treaty pre-emptively banned the projection of national sovereignty into outer space through territorial claims, in anticipation of off-world military bases or nuclear weapons platforms. What the Treaty had not foreseen and arguably does not explicitly prohibit is the appropriation of space resources by private, non-national actors. A direct prohibition on 
the private appropriation of space resources had been attempted in the Moon Agreement (1979), but its widespread ratification was defeated by US-based lobbying.

The defeat of the Moon Agreement occurs during an interesting confluence of interests in the late 1970s and early 1980s - a period that marks the beginnings of Reaganite neoliberalism. One NewSpace organisation hired the US-based lawyer-lobbyist Leigh Ratiner to oppose the Moon Agreement; Ratiner was also retained by a suite of mining interests to oppose the sea-bed mining provisions of UNCLOS III (Michaud, 1986: 90-93). Among these clients were the American multinationals Kennecott and Noranda Mining, both of which benefitted from the 'capitalist fascism' (Samuelson, 1983) the Pinochet regime established in consultation with the MPS. Both treaties described extra-territorial mineral resources as the 'common heritage of mankind': a legal concept of common ownership put forth by the G-77 nations as part of their New International Economic Order (NIEO) platform, adopted in 1974 by the UN General Assembly. Bair (2009) has documented the role of MPS economists and Heritage Foundation personnel (a citadel of the Atlas Network) in defeating a key instrument of the NIEO: a code of conduct to be observed by multinational corporations operating in developing countries, requiring they respect the political sovereignty and laws of those nations.

The pursuit of the geopolitical strategies of mining interests via the Atlas network can be traced through the UNCLOS III negotiations. Heritage and Cato were outspoken opponents of the G-77 and the 'common heritage of mankind' principle (e.g. Bandow, 1982), and their opposition to UN international laws of the commons would become central to the incoming Reagan Administrations' foreign policy. James Malone, a writer on the Heritage Foundation's first Mandate for Leadership volume (Heatherly \& Feulner, 1981) ${ }_{1}^{14}$ would work with Ratiner after being appointed by President Reagan to represent the US at the UNCLOS negotiations while Assistant Secretary for Oceans and International Environmental and Scientific Affairs. Malone later returned to Heritage, where he defined what became the default goal of US climate treaty negotiators in a policy briefing prepared ahead of the 1992 Rio Earth Summit: "Do not draft a plan for reducing specific quantities of 'greenhouse gases' by a set date" (Gacek \& Malone, 1992: 8).

\section{Conclusion}

As the international relations theorist David Chandler (2017) observes, the Anthropocene "collapses the foundations" of political modernity as "subject-centred rationalism and anthropocentric norms, discourses, and regulations", even as the "speed and energy of planetary changes overwhelm existing political institutions, from national parliaments to UN organisations." Thus, for some, the belated recognition of our collective geological agency demands that it be made intentional. Crutzen's (2002) statement of the Anthropocene thesis concludes with a call for a technocratic bypassing of the political sphere with speculative 'geoengineering' interventions, licensing dreams of a decisionist elite exerting technological control over the Earth's solar radiation balance, and further procrastination in the urgently needed phase-out of fossil-fuel combustion. A critical approach to the question of geological power might take the humbler position that what may yet be in our power to influence, through socio-technical change, political movements, democratic institutions, and law are the energetic-material practices through which we interact with the Earth and its future.

Here, we would highlight one aspect of our discussion of mineral sovereignty for researchers and activists, who in tracing the financing of organised opposition to climate policy to fossil-fuel interests and "conservative foundations", are often incognisant of the fact they have uncovered the neoliberal infrastructure of the Atlas Network (e.g. Brulle, 2014). Conversely, research on the genealogy of 


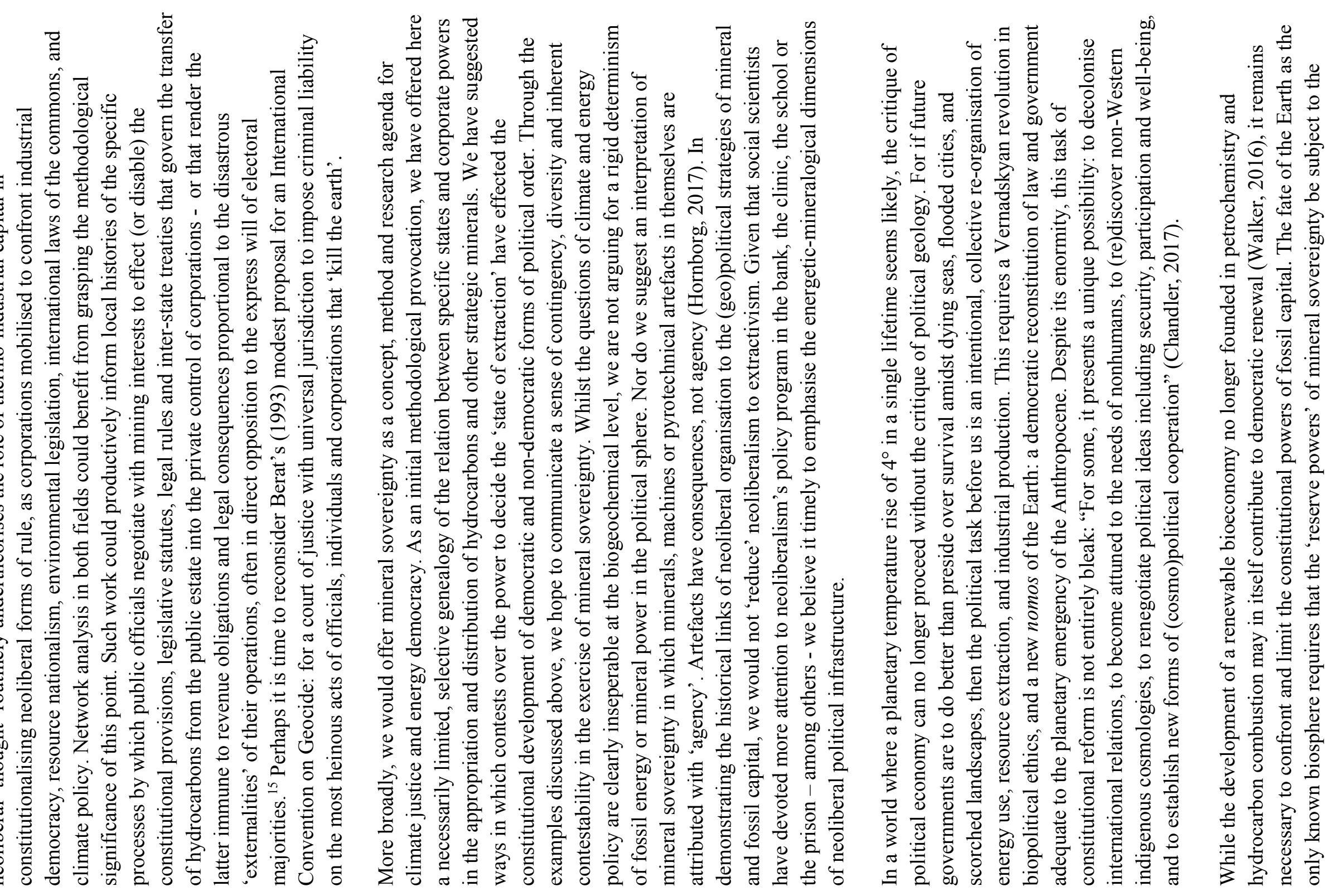


common interest, not only of Earth's peoples, but of the generations to come of all life exposed to potentially unendurable changes in the heat and chemistry of ocean and sky.

\section{Acknowledgements}

The authors would like to acknowledge valuable comments on earlier drafts offered by three anonymous reviewers, the editors of this special issue, and participants in the Knowledge/Culture/Ecologies 2017 conference at the University of Diego Portales (Santiago de Chile) where this paper was first presented. Matt Johnson's research was supported by an Australian Government Research Training Scheme scholarship.

\section{References}

** At the time of submission, all links were current.

Altvater, E., Crist, E., Haraway, D., Hartley, D., Parenti, C., \& McBrien, J. (eds) (2016). Anthropocene or capitalocene? Nature, history, and the crisis of capitalism. PM Press.

Agamben, G. (1998) Homo sacer: Sovereign power and bare life, Stanford University Press.

Bair, J. (2009) Taking aim at the New International Economic Order. In Mirowski, P. \& Plewhe, D. (eds), The road from Mont Pèlerin: the making of the neoliberal thought collective, Harvard University Press, 347-385.

Bandow, D. (1982) Developing the mineral resources of the seabed, Cato Journal, (2): 793.

Blackstone, W. (1898) Commentaries on the laws of England in four books, Liberty Fund. http://oll.libertyfund.org/titles/blackstone-commentaries-on-the-laws-of-england-in-four-books-vol-1

Bebr, G. (1953) The European Coal and Steel Community: A political and legal innovation. Yale Law Journal, 63 (1).

Berat, L. (1993). Defending the right to a healthy environment: Toward a crime of geocide in international law. Boston University International Law Journal, 11, 327.

Bonefeld, W. (2017) Authoritarian liberalism: From Schmitt via ordoliberalism to the Euro. Critical Sociology, 43(4-5), 747-761.

Braverman, I. (2014) Who's afraid of methodology? Advocating a methodological turn in legal geography. In The expanding spaces of law: A timely legal geography, I. Braverman, N. Blomley, D. Delaney \& A. Kedar (eds), Stanford University Press, 120-141

Brulle, R. (2014) Institutionalising delay: foundation funding and the creation of US climate change counter-movements, Climatic Change 122: 681-694. 
Burke, M. \& Stephens, J. (2018) Political power and renewable energy futures: A critical review. Energy Research \& Social Science 35, 78-93.

Carr, C. (1913) (ed.) Select charters of the trading companies A.D. 1530-1707, Selden Society, London.

Chandler, D. (2017) Call for Papers: Anthropocene politics: International relations after the end of the world, Section 03; European International Studies Association Pan-European Conference, Prague, September 2018.

Chatham House (2015) 'Transcript:Q\&A - 19 February 2015', Corporate Leaders Series, Chatham House, London. https://www.chathamhouse.org/

Clark, N. (2017) Politics of strata. Theory, Culture \& Society, 34(2-3) 211-231.

Colman, T. (2010) Gold in Britain: Past, present and future, Mercian Geologist, 14(3).

Colton, C. (2017) Contestability 'theory', its links with Australia's competition policy, and recent international trade and investment agreements. Australian Journal of International Affairs, 71(3), 315-334.

Cristi, R. (1984) Hayek and Schmitt on the rule of law. Canadian Journal of Political Science/Revue canadienne de science politique, 17(3), 521-535.

Crutzen, P. (2002) Geology of mankind. Nature, 415(6867), 23-23.

de Zwart, M. (23 June 2018) The international context of Trump's Space Force. Australian Institute of International Affairs. http://www.internationalaffairs.org.au/australianoutlook/international-contexttrump-space-forcel

Dean, M. (2012) Free economy, strong state. In Cahill, D., Edwards, L. \& Stillwell, F. (eds) Neoliberalism: beyond the free market, Edward Elgar, 69-89.

Director, A. \& Levi. E. (1956) Law and the future: trade regulation. Northwestern University Law Review, 51 281-296.

Elden, S. (2013) Secure the volume: Vertical geopolitics and the depth of power. Political Geography, 34, 35-51.

Emel, J., Huber, M. \& Makene, M. (2011) Extracting sovereignty: Capital, territory, and gold mining in Tanzania. Political Geography, (30): 70-79.

Engels, F. ([1887] 1998) Condition of the Working Class in England. www.Marxists.org

Farrant, A., \& Tarko, V. (2018) James M. Buchanan's 1981 visit to Chile: Knightian democrat or defender of the 'Devil's fix'?. The Review of Austrian Economics, 1-20.

Filer, C. (1996) 'Between a rock and a hard place: mining, "indigenous people": and the development of states', Australian National University, 8-19. 
Fischer, K. (2009) The influence of neoliberals in Chile before, during and after Pinochet. In Mirowski, P. \& Plewhe, D. (eds) The Road from Mont Pèlerin: the making of the neoliberal thought collective, Harvard University Press, 305-306.

Fisher, D. (1980) American philanthropy and the social sciences in Britain, 1919-1939; the reproduction of a conservative ideology. Sociological Review, 28(2), 277-315.

Frank, A. G. (1976) Economic genocide in Chile: Open letter to Milton Friedman and Arnold Harberger. Economic and Political Weekly, 880-888.

Gacek, C. \& Malone, J. (1992) Guidelines for the U.N. Environmental Conference, Backgrounder, no.874, Heritage Foundation, Washington, D.C.

Georgescu-Roegen, N. (1971) The entropy law and the economic process, Harvard University Press.

Gillingham, J. (2014) Industry and politics in the Third Reich: Ruhr coal, Hitler and Europe.

Routledge.

Gray, K. (1991) Property in thin air. Cambridge Law Journal, 50 (2): 252-307.

Guillame, B. (2014) Vernadsky's philosophical legacy: a perspective from the Anthropocene, Anthropocene Review, 1 (2): 137-146.

Goodman, J. (2009). From global justice to climate justice? Justice ecologism in an era of global warming. New Political Science, 31(4): 499-514.

Grinevald, J. (1998) Introduction: the invisibility of the Vernadskyan revolution, in Vernadsky, V. ([1926] 1998) The Biosphere, Copernicus, New York, 20-32.

Habermas, J. (1997) Popular sovereignty as procedure. Deliberative democracy: Essays on reason and politics, 35-65.

Hayek, F. ([1944] 2007) The road to serfdom. University of Chicago Press.

Heatherly, C., \& Feulner, E. (1981) Mandate for leadership: Policy management in a conservative administration. Heritage Foundation, Washington, D.C.

Hirsh, R., \& Jones, C. (2014) History's contributions to energy research and policy. Energy Research \& Social Science, 1, 106-111.

Hornborg, A. (2017) Artifacts have consequences, not agency: Toward a critical theory of global environmental history. European Journal of Social Theory, 20(1), 95-110.

Hudgins, E. (2002) (Ed.) Space: The free market frontier, Washington : Cato Institute.

Hyde Price, W. (1906), The English patents of monopoly, The University Press, Cambridge. 
Johnson, M. (2018) 'Privateering on the cosmic frontier? Mining celestial bodies and the 'NewSpace' quest for private property in outer space', In Arvanitakis, J. \& Fredriksson, M. (eds), Property, Place and Piracy, Routledge, Abingdon, 123-139.

Kaiser, D., \& Wasserman, L. (2016) The Rockefeller Family Fund vs Exxon. 8 December. New York Review of Books. http://www.nybooks.com/articles/2016/12/08/the-rockefellerfamilyfund-vs-exxon/

Kantorowicz, E. (1957) The King's two bodies: A study in medieval political theory. Princeton University Press.

Kearnes, M., \& Rickards, L. (2017) Earthly graves for environmental futures: Techno-burial practices. Futures, 92, 48-58.

Kilgore, D. (2003) Astrofuturism: Science, race and visions of utopia in space, University of Pennsylvania Press, Philadelphia.

Kopenawa, D. with Albert, B. (2013) The falling sky: words of a Yanomami shaman, Harvard University Press.

Lucas, A. (2018) Revealed: the extent of job-swapping between public servants and fossil fuel lobbyists. University of Wollongong, 5 March, https://media.uow.edu.au/opinions/UOW244161.html

MacLean, N. (2017) Democracy in chains: The deep history of the radical right's stealth plan for America. Penguin.

Malm, A. (2016) Fossil capital: the rise of steam-power and the roots of global warming, Verso, London.

Malm, A., \& Hornborg, A. (2014) The geology of mankind? A critique of the Anthropocene narrative. Anthropocene Review, 1(1), 62-69.

Marder, M. (2015) The Enlightenment, pyropolitics, and the problem of evil. Political Theology, 16(2), 146-158.

McGee, J. S. (1958) Predatory price cutting: the Standard Oil (NJ) case. The Journal of Law and Economics, 1, 137-169.

Michaud, M. (1986) Reaching for the high frontier: The American Pro-Space movement, 1972-84. New York: Praeger.

Minca, C., \& Rowan, R. (2015) On Schmitt and space. Routledge.

Mirowski, P. \& Plewhe, D. (eds) (2009) The road from Mont Pèlerin: the making of the neoliberal thought collective, Harvard University Press: Cambridge MA.

Mitchell, T. (2009). Carbon democracy. Economy and Society, 38(3): 399-432. 
Montague, D. (2002) Stolen goods: Coltan and conflict in the Democratic Republic of Congo. SAIS Review, 22 (1): 103-118.

Moore, J. (2010) "This lofty mountain of silver could conquer the whole world": Potosí and the political ecology of underdevelopment, 1545-1800', Journal of Philosophical Economics, 4(1): 59103.

Müller, J. (2014) On conceptual history. Rethinking modern European intellectual history, Oxford University Press, 74-93.

Mumford, L. (1962) Technics and civilisation. Routledge and Kegan, London.

Nef, J. (1964) The conquest of the material world, UCP, Chicago.

O’Neill, G. (1975) Testimony: Space colonization and energy supply to Earth, Subcommittee on Space Science Applications hearings, 23 July (House Committee on Science and Technology), https://settlement.arc.nasa.gov/CoEvolutionBook/TESTIM.HTML

O’Neill, G. (1977) The high frontier: Human colonies in outer space, Morrow, New York.

Paul, S. (Dec 8 2017) ExxonMobil, Chevron, Shell paid no tax in Australia for 2016, says ATO. Financial Review. http://www.afr.com/business/energy/oil/exxonmobil-chevron-shell-paid-no-tax-inaustralia-for-2016-says-ato-20171208-h017bz

Planetary Resources (2015). President Obama Signs Bill Recognizing Asteroid Resource Property Rights into Law [press release], 25 November. Redmond, WA: Planetary Resources. Retrieved from www.planetaryresources.com/2015/11/president-obama-signsbill-recognizing-asteroid-resource-property-rights-into-law/

Purdy, J. (2014) Neoliberal constitutionalism: Lochnerism for a new economy. Law \& Contemporary Problems, (77): 195.

Raji, D. \& A. Abedjie (2014) The British mining and oil regulations in colonial Nigeria c. 19141960s: an assessment. Singaporean Journal of Business, Economics and Management Studies, 2(10): $62-75$.

Rhodes, C. \& Stead, W. (ed) (1902) The Last Will and Testament of Cecil John Rhodes.

Samuelson, P. (1983) The world economy at century's end. In S. Tsuru (Ed.), Human resources, employment and development (pp. 58-94). London: Palgrave Macmillan.

Scheuerman, W. (1997) The unholy alliance of Carl Schmitt and Friedrich A. Hayek. Constellations, $4(2), 172-188$.

Schmitt, C. ([1922] 1985) Political theology: Four chapters on the concept of sovereignty. University of Chicago Press.

Schmitt, C. (2006) The nomos of the Earth in the international law of the Jus Publicum 
Europaeum, New York: Telos.

Schneidermann, D. (2017) 'Investor rights and the judicial denial of neoliberal constitutionalism', in S. Archer, D. Drache, P. Zumbansen (eds), The daunting enterprise of the law. Montreal: McGill/Queens UP.

Shiva, V. (2016) Earth democracy: Justice, sustainability and peace. Zed.

Simberg, R. (2012) Homesteading the final frontier: a practical proposal for securing property rights in space, Issue Analysis, no.3. Competitive Enterprise Institute, Washington, D.C.

Simons, H. (1948) Economic policy for a free society. University of Chicago Press.

Smith, L. T. (2013) Decolonizing methodologies: Research and indigenous peoples. Zed.

Snow, C. P. (1959) The two cultures and the scientific revolution: The Rede Lecture, 1959. University Press.

Swyngedouw, E., \& Ernstson, H. (2018) Interrupting the Anthropo-obScene: immuno-biopolitics and depoliticizing more-than-human ontologies in the Anthropocene. Theory, Culture and Society, 1-28.

Thorpe, F. (ed) (1909) The Federal and state constitutions, colonial charters, and other organic laws of the state, territories, and colonies now or heretofore forming the United States of America, Government Printing Office, Washington.

U.S. Congress (1988) Office of Technology Assessment, Copper: Technology and Competitiveness. OTA-E-367, US Government Printing Office, Washington, DC.

Tienhaara, K. (2006) What you don't know can hurt you: investor-state disputes and the protection of the environment in developing countries. Global Environmental Politics, 6(4), 73-100.

United Nations (1967) Treaty on Principles Governing the Activities of States in the Exploration and Use of Outer Space, including the Moon and Other Celestial Bodies. New York, United Nations, Treaty Series, 610 (8843).

US Commercial Space Launch Competitiveness Act (2015) H.R. 2262, §§401-403.

Van Horn, R. (2010) Chicago's shifting attitude toward concentrations of business power (19341962). Seattle University Law Review, 34, 1527.

Van Horn, R. \& Mirowski, P. (2008) The rise of the Chicago School of economics and the birth of neoliberalism. In Mirowski, P. \& Plewhe, D. (eds) (2009) The road from Mont Pèlerin, Harvard University Press: Cambridge MA, 139-180.

Vernadsky, V. (1924) La géochimie. Paris: Félix Alcan.

Vernadsky, V. ([1926] 1998) The biosphere, Copernicus, New York. 
Vatter, M. (2018) Neoliberalism and republicanism: economic rule of law, and law as concrete order (nomos). In Cahill, D, Cooper, M. Kojnings, M, Primrose, D. (eds) The SAGE handbook of neoliberalism, SAGE.

Wainwright, J., \& Mann, G. (2013) Climate leviathan. Antipode, 45(1), 1-22.

Walker, J. (2016) The creation to come: pre-empting the evolution of the bioeconomy. In Marshall, J. \& Connor, L. (eds), Environmental change and the world's futures: Ecologies, ontologies and mythologies, Routledge, 264-281.

Wertime, T. (1954) Discovery of the element carbon. Osiris, 11, 211-220.

\begin{abstract}
${ }^{1}$ As we approach the present, it is clear that mining capital threatens returns to agriculture not only through global warming and altered climactic conditions, but also directly competes with it for land and water, evident in resistance to mine expansions by farmers rallying under the banner of 'food sovereignty'.
\end{abstract}

${ }^{2}$ We are indebted to Kearnes \& Rickard (2017) for this reference.

${ }^{3}$ We owe this insight to Matt Kearnes and Declan Kuch.

${ }^{4}$ It is beyond the scope of this article to consider the specific diversity in mining law. For example, the General Mining Act (1872) of the United States -still in operation to this day -allows individuals and companies to claim property in 'royal' and certain other minerals beneath public lands with no obligation to pay royalties. The Mining Leasing Act (1920) exempted hydrocarbons from this generous gifting. In Australia, which makes no mention of land in its Constitution, all minerals are effectively reserved to the Crown by various acts of federal and state legislation. Through lucrative investments in political infrastructure, many multinational energy miners have effectively reduced their Australian tax obligations and royalties to zero in recent years (e.g. Paul, 2017), despite the enormous volumes of resources appropriated and the scale of their revenues.

${ }^{5}$ Since the pitched battles of the 1930s Harlan County war, during which the National Labour Relations Act (1935) outlawing the anti-union tactics of mining companies went unenforced, the coal operators of Virginia and Kentucky have successfully repressed the attempts of impoverished mining communities to organise. They were central in organising the Byrd-Hagel Resolution (1997) which blocked US ratification of the Kyoto Protocol, and the 'Trump digs coal' campaign of the current president.

${ }^{6}$ See Scheuerman (1997) on the proximity of Schmitt's drastic critique of the Weimar welfare state to Hayek's critique of 'unlimited' democracy, and Vatter (2018) on the relation between Schmitt's nomos and Hayek's rule of (economic) law. Cristi (1984) and Bonefeld (2017) characterise Schmitt and Hayek as exponents of 'authoritarian liberalism'.

${ }^{7}$ Through expansive, discretely-made international investments in social science research, the Rockerfeller Foundation shaped the functionalist turn of early $20^{\text {th }}$ century social science. This 'philanthropy' was one response to public outcry against the Rockefellers in the wake of the 1914 Ludlow massacre, when striking mineworkers and their families were killed by security forces in the pay of Rockerfeller-owned coal mines in Colorado (Fisher, 1980: 306).

${ }^{8}$ The Rockefeller Foundation declined Hayek's funding requests, citing the need to maintain an acceptably centrist, non-partisan public image. 
${ }^{9}$ The Trans-Arabian Pipeline was constructed by the Bechtel Corporation, now a strategic partner with space mining start-up Planetary Resources. Bechtel was also one of several foreign companies involved in coltan mining in what is now the Democratic Republic of Congo, and is reported to have hired NASA satellites to make mineralogical surveys of the region, providing military and mineral resource intelligence to the various armed forces that violently destabilised the Republic of Zaire (Montague, 2002: 110).

${ }^{10}$ Through a series of mergers and acquisitions, ExxonMobil represents a signficant reconsolidation of many of the 34 companies that the Standard Oil monopoly was broken into following Standard Oil Co. of New Jersey v. United States, 221 U.S. 1 (1911). For the Greenpeace list, see: https://exxonsecrets.org/html/listorganizations.php; for the Atlas Network list, see: https://www.atlasnetwork.org/partners/global-directory.

${ }^{11}$ Trump's public unpredictability has tempted commentators to view has presidency as an aberration. His legislative agenda shows historical continuity with Republican policymaking: see endnote 14.

${ }^{12}$ Cecil Rhodes, founder of the royal-chartered British South Africa Company and the De Beers diamond mines, lamented in his twilight years that the "world is nearly all parcelled out, and what there is left of it is being divided up, conquered and colonised. To think of these stars that you see overhead at night, these vast worlds which we can never reach. I would annex the planets if I could; I often think of that. It makes me sad to see them so clear and yet so far" (Rhodes \& Stead, 1902).

${ }^{13}$ Here we would note President Trump's call for a new branch of the military, a Space Force with which to convert mere "American presence in space" into "American dominance in space" (de Zwart, 2018).

${ }^{14}$ The blueprint for Reagan's legislative program was a volume prepared by the Heritage Foundation called Mandate for Leadership, as has been the case with all incoming Republican administrations since, the Trump Administration included.

${ }^{15}$ This is an approach that could expand on network analysis such as that undertaken by Lucas (2018), who details personnel movements through the 'revolving doors' between the Australian public service and the multinational fossil fuel lobby, and up the resulting 'golden escalators'. It might inform the work of divestment committees, such as that of the Rockefeller Family Fund, who hired investigative journalists to reveal the network of 'front groups' ExxonMobil used to attack climate science (Kaiser \& Wasserman, 2016). 